\title{
CHARACTERIZATION OF ACETYLCHOLINESTERASE FROM THE BRAIN OF THE AMAZONIAN TAMBAQUI (COLOSSOMA MACROPOMUM) AND IN VITRO EFFECT OF ORGANOPHOSPHORUS AND CARBAMATE PESTICIDES
}

\author{
Caio Rodrigo Dias Assis, $\nmid$ Patrícia Fernandes Castro, $\ddagger$ Ian Porto Gurgel Amaral,$\dagger$ \\ Elba Verônica Matoso Maciel Carvalho, $\dagger$ Luiz Bezerra Carvalho Jr, $\dagger$ and Ranilson Souza Bezerra* $\dagger$ \\ $\dagger$ †aboratório de Enzimologia, LABENZ, Departamento de Bioquímica and Laboratório de Imunopatologia Keizo Asami, \\ Universidade Federal de Pernambuco, Pernambuco, Brazil \\ $\ddagger$ Empresa Brasileira de Pesquisa Agropecuária, Embrapa Meio-Norte, Parnaíba-PI, Brazil
}

(Submitted 11 January 2010; Returned for Revision 12 March 2010; Accepted 23 April 2010)

\begin{abstract}
In the present study, acetylcholinesterase (AChE) from the brain of the Amazonian fish tambaqui (Colossoma macropomum) was partially characterized and its activity was assayed in the presence of five organophosphates (dichlorvos, diazinon, chlorpyrifos, and tetraethyl pyrophosphate [TEPP]) and two carbamates (carbaryl and carbofuran) insecticides. Optimal pH and temperature were 7.0 to 8.0 and $45^{\circ} \mathrm{C}$, respectively. The enzyme retained approximately $70 \%$ of activity after incubation at $50^{\circ} \mathrm{C}$ for $30 \mathrm{~min}$. The insecticide concentration capable of inhibiting half of the enzyme activity (IC50) for dichlorvos, chlorpyrifos, and TEPP were calculated as $0.04 \mu \mathrm{mol} / \mathrm{L}, 7.6 \mu \mathrm{mol} / \mathrm{L}$, and $3.7 \mu \mathrm{mol} / \mathrm{L}$, respectively. Diazinon and temephos did not inhibit the enzyme. The IC50 values for carbaryl and carbofuran were estimated as $33.8 \mu \mathrm{mol} / \mathrm{L}$ and $0.92 \mu \mathrm{mol} / \mathrm{L}$, respectively. These results suggest that AChE from the juvenile $C$. macropomum brain could be used as an alternative biocomponent of organophosphorus and carbamate biosensors in routine pesticide screening in the environment. Environ. Toxicol. Chem. 2010;29:2243-2248. (C) 2010 SETAC
\end{abstract}

Keywords-Organophosphorus pesticide Carbamate pesticide Acetylcholinesterase Biomarkers Colossoma macropomum

\section{INTRODUCTION}

Organophosphorus and carbamate are major classes of pesticides in use throughout the world. Together, they share about $50 \%$ of the world market of insecticides/acaricides. Their relatively fast hydrolysis and low persistence in the environment have supported their increasing use. However, their toxicity to mammals and other nontarget organisms, together with the large amounts used, constitute a threat to human health and the environment. Both classes are cholinesterase inhibitors, and several methodologies have been developed using these enzymes from various species to monitor their environmental presence. These neurotoxic agents have been distributed throughout the world without control in recent decades and, due to misuse and a lack of specificity, have become a serious problem to both humans and the environment [1]. Therefore, methods for organophosphorus and carbamate detection using either organisms or their enzymes as bioindicators and biomarkers, respectively, have been evaluated [2,3]. The cholinesterase group stands out among such molecules [4-6].

Acetylcholinesterase (AChE; enzyme classification 3.1.1.7) is widely known as a specific biomarker of organophosphorus and carbamate pesticides due to the inhibition of its activity [7]. This enzyme is responsible for modulating neural communication in the synaptic cleft by hydrolyzing the ubiquitous neurotransmitter acetylcholine. A lack of AChE activity causes central and peripheral nervous system disorders and death [8].

Studies have confirmed cholinesterases as suitable for monitoring the occurrence of these pesticide classes in environ-

\footnotetext{
* To whom correspondence may be addressed (ransoube@uol.com.br).

Published online 1 June 2010 in Wiley Online Library (wileyonlinelibrary.com).
}

mental compartments [6,9-11]. For example, biosensors have been proposed based on $\mathrm{AChE}$ from electric eel and both genetically engineered (B394) and wild-type strains of Drosophila melanogaster [12]. However, the high interspecific and intraspecific polymorphism of these enzymes cause varied responses to insecticide compounds, thereby hindering the evaluation and comparison of results from different studies [13]. Consequently, it is necessary to characterize AChE activity in each species and type of tissue.

In previous work, $\mathrm{AChE}$ from the brain of the juvenile Amazonian fish tambaqui (Colossoma macropomum) was shown to be sensitive to dichlorvos [14]. This enzyme source could be proposed as a feasible alternative for setting up biosensors once it is located in a discarded tissue (brain) of this fish, which is the third most farmed species in Brazil (30,598 tons in 2007, according to the Brazilian Ministry of Environment; http://www.ibama.gov.br/recursos-pesqueiros/ documentos/estatistica-pesqueira/).

The aims of the present study were to partially characterize some kinetic and physicochemical parameters of this enzyme, and to evaluate the effect of seven relevant organophosphorus and carbamate pesticides on its activity, to propose it as the biocomponent of an in vitro biosensor.

\section{MATERIALS AND METHODS}

Acetylthiocholine iodide, bovine serum albumin, 5,5'dithiobis(2-nitrobenzoic) acid (DTNB), Tris (hydroxymethyl) aminomethane, and dimethyl sulfoxide were purchased from Sigma. Analytical grade dichlorvos (98.8\%), diazinon (99.0\%), chlorpyrifos $(99.5 \%)$, temephos $(97.5 \%)$, tetraethyl pyrophosphate $(97.4 \%)$, carbofuran $(99.9 \%)$, and carbaryl $(99.8 \%)$ were obtained from Riedel-de-Haën, Pestanal ${ }^{\circledR}$. Disodium hydrogen 
phosphate and $\mathrm{HCl}$ were obtained from Merck. Trisodium citrate was acquired from Vetec. Glycine was acquired from Amersham Biosciences. The spectrophotometer used was BioRad Smartspec ${ }^{\mathrm{TM}}$ 3000. The juvenile specimens of $C$. macropomum were supplied by Mar Doce Piscicultura e Projetos. Tambaqui specimens, $16.5 \pm 3.7 \mathrm{~cm}$ in length and $93.8 \pm 7.9 \mathrm{~g}$ in weight, were captured from a $750-\mathrm{m}^{3}$ pond.

\section{Enzyme extraction}

Twenty juvenile fish were acclimatized in 100-L aquaria (dissolved oxygen $8.04 \pm 0.05 \mathrm{mg} / \mathrm{L}$, temperature $26.04 \pm$ $0.07^{\circ} \mathrm{C}, \mathrm{pH} 6.93 \pm 0.22$, salinity $\left.0.17 \mathrm{~g} / \mathrm{L}\right)$ for one week and then sacrificed by immersion in an ice bath $\left(0^{\circ} \mathrm{C}\right)$. The brains were immediately removed, joined in pairs, and homogenized in $0.5 \mathrm{~mol} / \mathrm{L}$ Tris- $\mathrm{HCl}$ buffer, $\mathrm{pH} 8.0$, maintaining a ratio of $20 \mathrm{mg}$ of tissue per $\mathrm{ml}$ of buffer using a Potter-Elvehjem tissue disrupter. The homogenates were centrifuged for $10 \mathrm{~min}$ at $1,000 \mathrm{~g}\left(4^{\circ} \mathrm{C}\right)$ and the supernatants (crude extracts) were frozen at $-20^{\circ} \mathrm{C}$.

\section{Enzyme activity and protein determination}

The crude extract $(30 \mu \mathrm{l})$ was added to $500 \mu \mathrm{l}$ of $0.25 \mathrm{mmol} / \mathrm{L}$ DTNB dissolved in $0.5 \mathrm{~mol} / \mathrm{L}$ Tris- $\mathrm{HCl}$ buffer, $\mathrm{pH} 7.4$, and the reaction started by the addition of $0.125 \mathrm{~mol} / \mathrm{L}$ acetylthiocholine iodide $(30 \mu \mathrm{l})$ [14]. Enzyme activity (quadruplicate) was spectrophotometrically determined by following the absorbance at $405 \mathrm{~nm}$ for $180 \mathrm{~s}$, in which the reaction exhibited a first-order kinetics pattern [14]. A unit of activity (U) was defined as the amount of enzyme capable of converting $1 \mu \mathrm{mol}$ of substrate per minute. A blank assay was similarly prepared except that $0.5 \mathrm{~mol} / \mathrm{L}$ Tris- $\mathrm{HCl}$ buffer, $\mathrm{pH} 8.0$, replaced the crude extract sample. Protein content was estimated according to a modified dye-binding method [15], using bovine serum albumin as the standard.

\section{Optimal $\mathrm{pH}$ and temperature}

Assays were performed using DTNB solutions in a $\mathrm{pH}$ range from 2.5 to 9.5 by using citrate- $\mathrm{HCl}$ (2.5 to 4.5$)$, citratephosphate (4.0 to 7.5), Tris-HCl (7.2 to 9.0) buffers. Substrate nonenzymatic hydrolysis (in basic $\mathrm{pH}$ ) was corrected by subtracting their values from the activities. Optimum temperature was established by assaying the enzyme activity at temperatures ranging from 5 to $70^{\circ} \mathrm{C}$ for $180 \mathrm{~s}$.

\section{Thermal stability}

Thermal stability of juvenile C. macropomum AChE was evaluated by exposing crude extract samples for $30 \mathrm{~min}$ at temperatures ranging from 25 to $80^{\circ} \mathrm{C}$ and assaying the activity retained after $5 \mathrm{~min}$ of equilibration at $25^{\circ} \mathrm{C}$ (room temperature).

\section{Inhibition assay}

Acetylcholinesterase inhibition was assayed using five organophosphates (dichlorvos, diazinon, chlorpyrifos, temephos, and tetraethyl pyrophosphate [TEPP]) and two carbamates (carbaryl and carbofuran). The insecticides were first dissolved in dimethyl sulfoxide and then diluted in distilled water to five final concentrations ranging from 0.001 to $10 \mathrm{ppm}$, with each subsequent concentration 10-fold higher than the previous concentration. These concentrations correspond respectively: 0.0045 to $45.2 \mu \mathrm{mol} / \mathrm{L}$ (dichlorvos); 0.0032 to $32.8 \mu \mathrm{mol} / \mathrm{L}$ (diazinon); 0.0028 to $28.5 \mu \mathrm{mol} / \mathrm{L}$ (chlorpyrifos); 0.0021 to $21.4 \mu \mathrm{mol} / \mathrm{L}$ (temephos); 0.0034 to $34.5 \mu \mathrm{mol} / \mathrm{L}$ (TEPP); 0.0061 to $61.3 \mu \mathrm{mol} / \mathrm{L}$ (carbaryl); and 0.0045 to
$45.2 \mu \mathrm{mol} / \mathrm{L}$ (carbofuran). The insecticide solutions (10 $\mu \mathrm{l})$ were incubated with crude extract $(20 \mu \mathrm{l})$ for $1 \mathrm{~h}$ [14] and the residual activity (\%) was determined as previously described, using the absence of pesticide as $100 \%$ activity. All enzymatic and inhibition assays were carried out at room temperature $\left(25^{\circ} \mathrm{C}\right)$. Five crude extracts from 10 fish brains were analyzed in triplicate for each insecticide concentration and data were expressed as mean \pm standard deviation. These data were statistically analyzed by nonlinear regression fitted to polynomial or exponential decay $(p>0.05)$ modeling using the software MicroCal ${ }^{\circledR}$ Origin Version 8.0. The concentration capable of inhibiting half of the enzyme activity (IC50) was estimated for each pesticide.

\section{RESULTS AND DISCUSSION}

Optimum $\mathrm{pH}$ for juvenile C. macropomum $\mathrm{AChE}$ was found to be in the range 7.0 to 8.0 (Fig. 1A) similar to those described in the literature for other fishes (Table 1): Solea solea (7.0), Scomber scomber (8.0), and Pleuronectes platessa (8.5) [9]; Cymatogaster aggregate[16] and Hypostomus punctatus [17] (between 7.0 and 7.2). Optimum temperature was estimated as $45^{\circ} \mathrm{C}$ (Fig. 1B). Bocquené et al. [9] found temperatures in the range 32 to $34^{\circ} \mathrm{C}$ for Pleuronectes platessa; Beauvais et al. [4] at $25^{\circ} \mathrm{C}$ for Lepomis macrochirus, and Hazel [18] at $35^{\circ} \mathrm{C}$ for Carassius auratus. In the present study, AChE from juvenile
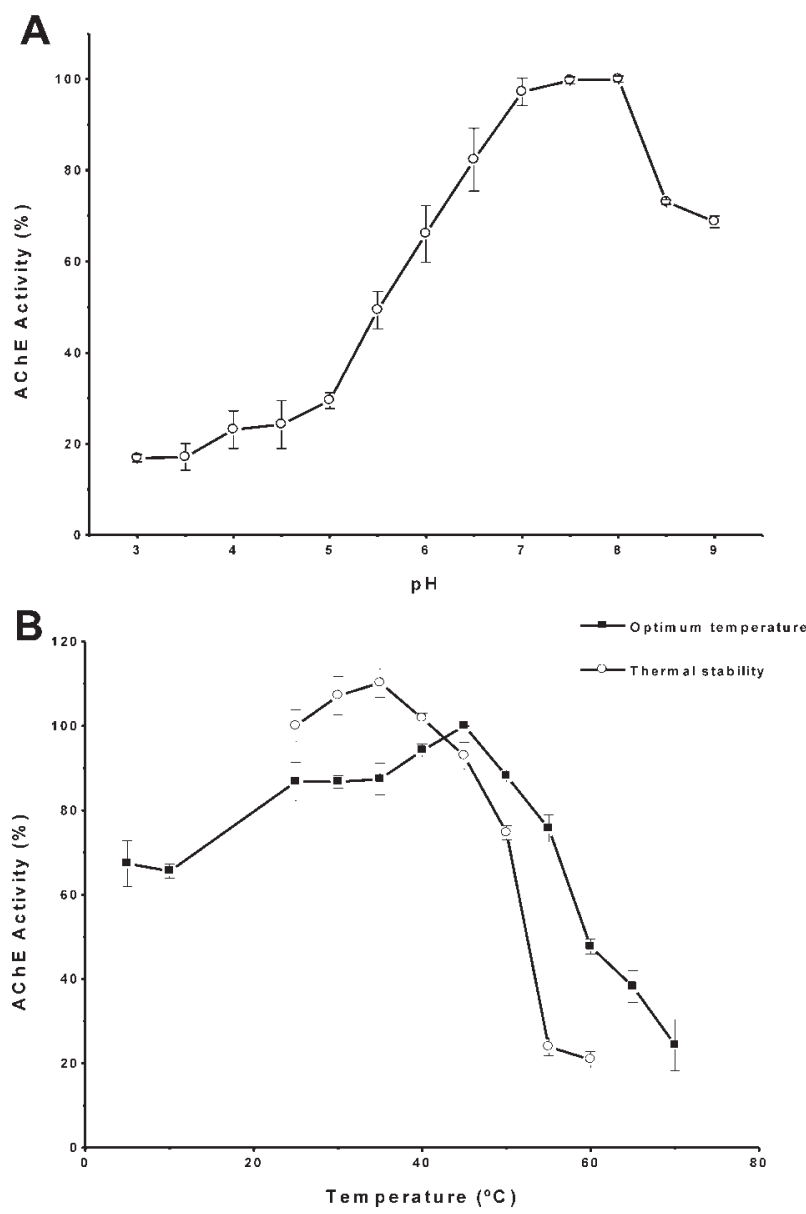

Fig. 1. Effect of $\mathrm{pH}(\mathbf{A})$ and temperature (B) on the AChE from brain of juvenile $C$. macropomum. The $\mathrm{pH}$ range was attained by using citrate-HCL, citrate-phosphate, and tris- $\mathrm{HCl}$ buffers, whereas the temperature effect was investigated either on the enzyme activity (optimum temperature, $\square$ ) or on the enzyme preparation (thermal stability, $\bigcirc)$ for $30 \mathrm{~min}$; after $5 \mathrm{~min}\left(25^{\circ} \mathrm{C}\right.$ equilibrium), its activity was estimated. $\mathrm{AChE}=$ acetylcholinesterase. 
Table 1. Kinetics and physicochemical parameters of AChE from some freshwater and marine species ${ }^{\mathrm{a}}$

\begin{tabular}{|c|c|c|c|c|c|c|}
\hline Species [reference] & $K_{\mathrm{m}}(\mathrm{mmol} / \mathrm{L})$ & $\begin{array}{c}V_{\max } \\
(\mathrm{U} / \mathrm{mg} \text { of protein) }\end{array}$ & Optimum pH & $\begin{array}{c}\text { Optimum } \\
\text { temperature }\left({ }^{\circ} \mathrm{C}\right)\end{array}$ & Source & Life stage \\
\hline Oreochromis niloticus[5] & $0.10 \pm 0.03$ & $0.229 \pm 0.014$ & ND & ND & Brain & Juvenile $48.2 \pm 3.9 \mathrm{~g}$ \\
\hline Pleuronectes vetulus[6] & $1.69 \pm 0.26$ & $0.482 \pm 0.034$ & ND & ND & Muscle & Juvenile $13.5-29.5 \mathrm{~cm}$ \\
\hline \multirow[t]{2}{*}{ Pleuronychtis verticalis [6] } & $0.30 \pm 0.07^{\mathrm{b}}$ & $0.524 \pm 0.032^{\mathrm{b}}$ & ND & ND & Muscle & Juvenile \\
\hline & $0.23 \pm 0.06^{\mathrm{c}}$ & $0.120 \pm 0.08^{\mathrm{c}}$ & & & & \\
\hline Solea solea $[9]$ & ND & ND & 7.5 & ND & Brain & ND \\
\hline Pleuronectes platessa [9] & ND & ND & 8.5 & 33 & Brain & ND \\
\hline Scomber scomber $[9]$ & ND & ND & 8.0 & ND & Brain & ND \\
\hline Colossoma macropomum [present work] & $0.43 \pm 0.02$ & $0.13 \pm 0.05$ & 7.5 & 45 & Brain & Juvenile $16.6 \pm 3.7 \mathrm{~cm}$ \\
\hline
\end{tabular}

${ }^{\mathrm{a}} \mathrm{AChE}=$ acetylcholinesterase $K_{\mathrm{m}}=$ Michaelis-Menten constant; $V_{\max }=$ maximum velocity of enzyme activity; ND $=$ not determined.

${ }^{\mathrm{b}}$ Female specimens.

${ }^{\mathrm{c}}$ Male specimens.

C. macropomum after being incubated for $30 \mathrm{~min}$ at $50^{\circ} \mathrm{C}$ retained about $70 \%$ of its activity at $35^{\circ} \mathrm{C}$ (Fig. 1B). Zinkl et al. [19] reported absence of cholinesterase activity in the brain of Oncorhyncus mykiss (formerly known as Salmo gairdneri) subjected to temperatures higher than $45^{\circ} \mathrm{C}$.

The Michaelis-Menten kinetics is displayed in Figure 2, from which the maximal velocity $\left(V_{\max }\right)$ and apparent bimolecular constant $\left(K_{\mathrm{m}}\right)$ were $0.128 \pm 0.005 \mathrm{U} / \mathrm{mg}$ protein and $0.434 \pm 0.025 \mathrm{mmol} / \mathrm{L}$, respectively, using acetylthiocholine iodide as substrate. The Lineweaver-Burk plot is also presented. Varó et al. [20] reported acetylthiocholine iodide inhibition at concentrations greater than $5.12 \mathrm{mmol} / \mathrm{L}$ in brain tissue from Sparus aurata, in contrast to muscle tissue, for which inhibition occurred at $20.48 \mathrm{mmol} / \mathrm{L}$. Rodríguez-Fuentes and Gold-Bouchot [5] found acetylthiocholine inhibition at $4.89 \mathrm{mmol} / \mathrm{L}$ in AChE from the brain of Oreochromis niloticus. However, in the present study, no substrate inhibition was observed even at the $15 \mathrm{mmol} / \mathrm{L}$ acetylthiocholine iodide. According to Table 1, the apparent Michaelis-Menten constant of the juvenile $C$. macropomum $\mathrm{AChE}$ was lower than that estimated for Pleuronectes vetulus muscle and higher than Pleuronychtis verticalis muscle and Oreochromis niloticus brain, whereas the maximum velocity was smaller than those reported for these mentioned tissues.

Among the anticholinesterasic agents, organophosphates and its analogues play a different role in the metabolic paths

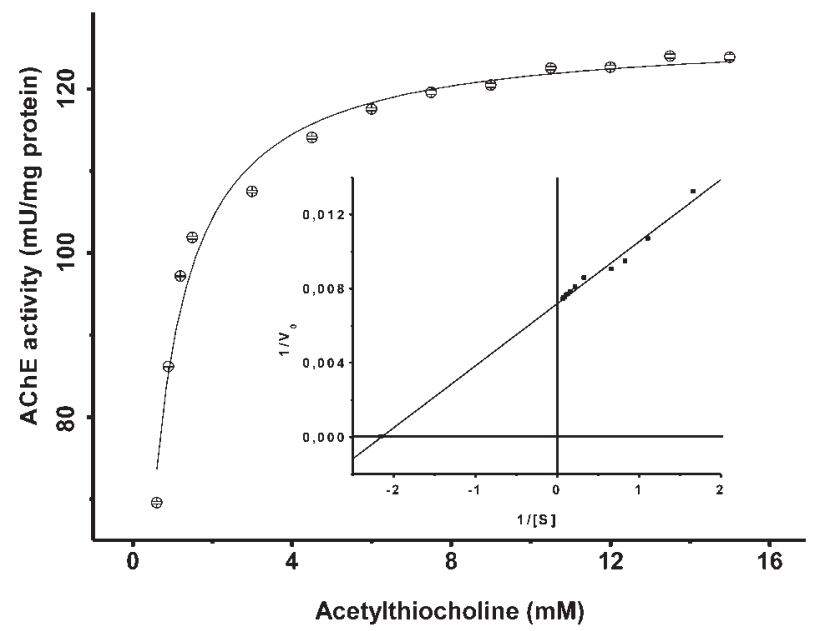

Fig. 2. Michaelis-Menten plot of the AChE from brain of juvenile C. macropomum acting on acetylthiocholine. Data are expressed as the mean \pm standard deviation of three replicates from four homogenates. The inset shows the Lineweaver-Burk plot. $\mathrm{AChE}=$ acetylcholinesterase. before reaching sites of neuronal transmission. Some of them are produced in a less toxic form (thion form, $\mathrm{P}=\mathrm{S}$ ) which is more stable in the environment. When absorbed by an organism, this form of pesticide undergoes bioactivation to a more toxic form (oxon form, $\mathrm{P}=\mathrm{O}$ ) by monooxigenases from the cytochrome $\mathrm{P} 450$ complex present in some organs/tissues including liver, kidneys, lungs, and brain. Therefore, this phenomenon and the diverse effect of the resulting products on the AChE can determine differences in the behavior of the enzyme.

The Food and Agriculture Organization [21] recommends that $20 \%$ inhibition is the relevant end-point to determine acceptable daily intakes of an anticholinesterasic compound. In the present study, some of the compounds analyzed were highly toxic to tambaqui $\mathrm{AChE}$, and the inhibition they caused could rapidly reach the above-mentioned levels.

Results from inhibition assays are displayed in Figure 3 and Table 2 and summarize the IC50 values estimated from these data for the five organophosphates (dichlorvos, diazinon, chlorpyrifos, temephos, and TEPP) and two carbamate insecticides (carbaryl and carbofuran). Dichlorvos as previously demonstrated [14] was shown to strongly inhibit the juvenile C. macropomum AChE. Among the investigated pesticides in the present study, this insecticide presented the lowest IC50 value $(0.04 \mu \mathrm{mol} / \mathrm{L} ; 0.01 \mathrm{ppm})$ and the lowest value compared with those reported in the literature for other fish species. Chuiko [22] estimated the IC50 value of $0.31 \mu \mathrm{mol} / \mathrm{L}$ for Leuciscus idus and Esox lucius, and $0.63 \mu \mathrm{mol} / \mathrm{L}$ for Alburnus alburnus. Dichlorvos is a direct inhibitor of AChE. It is an oxon organophosphate compound [23] and does not require bioactivation for enzyme inhibition in contrast with thion compounds, for which only a fraction of the total amount is activated in the tissues [24,25]. Chlorpyrifos also displayed lower IC50 value (7.6 $\mu \mathrm{mol} / \mathrm{L})$ than that reported for Cyprinus carpio [26]. Diazinon and temephos did not show inhibition effect on the juvenile C. macropomum AChE under the experimental conditions used in the present study. According to a number of studies, acute toxicity from phosphorothionate pesticides such as diazinon and chlorpyrifos is strongly influenced by differences in the activity of cytochrome P450-mixed oxidase systems, which bioactivate these compounds [27,28]. Nevertheless, these influences only determine toxic effects through the balance between activation and detoxification pathways: P450 dearylation, carboxylesterase and butyrylcholinesterase phosphorylation, and oxonase-mediated hydrolysis [29]. Thus, the contrast between high sensitivity to oxons and apparent lower oxidation activity possibly could be a $C$. macropomum enantiostatic mechanism when facing xenobiotic threats [30]. 

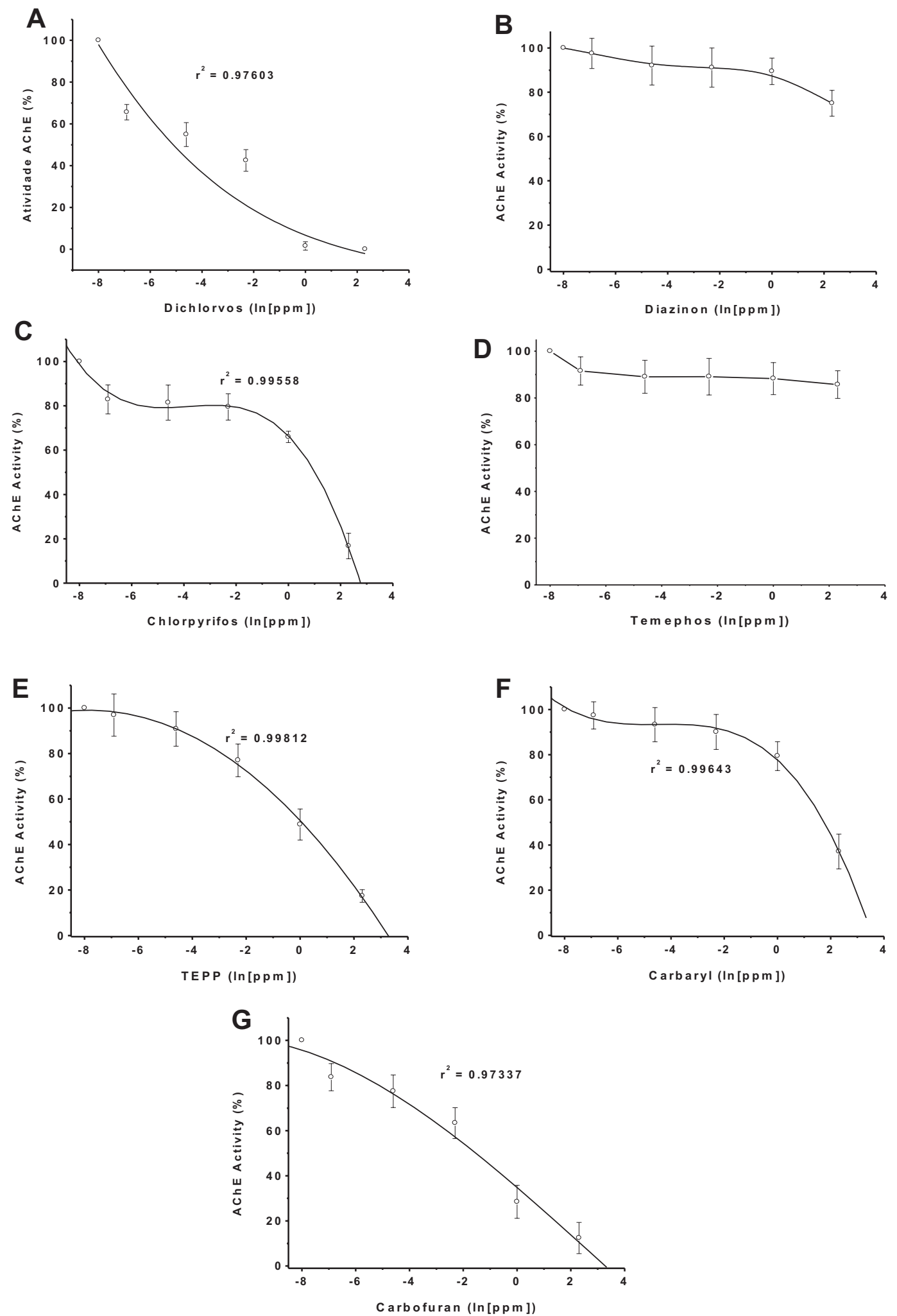

Fig. 3. Effect of organophosphates and carbamates on the activity of AChE from brain of juvenile C. macropomum. Dichlorvos (A), diazinon (B), chlorpyrifos (C), temephos $(\mathbf{D})$, TEPP $(\mathbf{E})$, carbaryl $(\mathbf{F})$, and carbofuran $(\mathbf{G})$ concentrations ranged from 0.001 to $10 \mathrm{ppm}$. All the assays were performed at $25^{\circ} \mathrm{C}$, and the experimental points are the mean \pm standard deviation of triplicate of four crude extracts. $\mathrm{AChE}=$ acetylcholinesterase; TEPP $=$ tetraethyl pyrophosphate.

Another condition that may cause discrepancies, particularly in case of chlorpyrifos, is that this compound accumulates in tissues, which likely affects other results. Antwi [31] also found no statistical differences in four fish species (Oreochromis niloticus, Sarotherodon galilaea, Alestes nurse, and Schilbe mystus) between controls and individuals living in areas treated weekly with temephos over a six-year period. Temephos is also a thion compound, but the reasons for such results are not only caused by the circumstances mentioned for diazinon and chlorpyrifos. This pesticide is known to exhibit moderate to low 
Table 2. Pesticide IC50 values for in vitro freshwater fish ${ }^{\mathrm{a}, \mathrm{b}}$

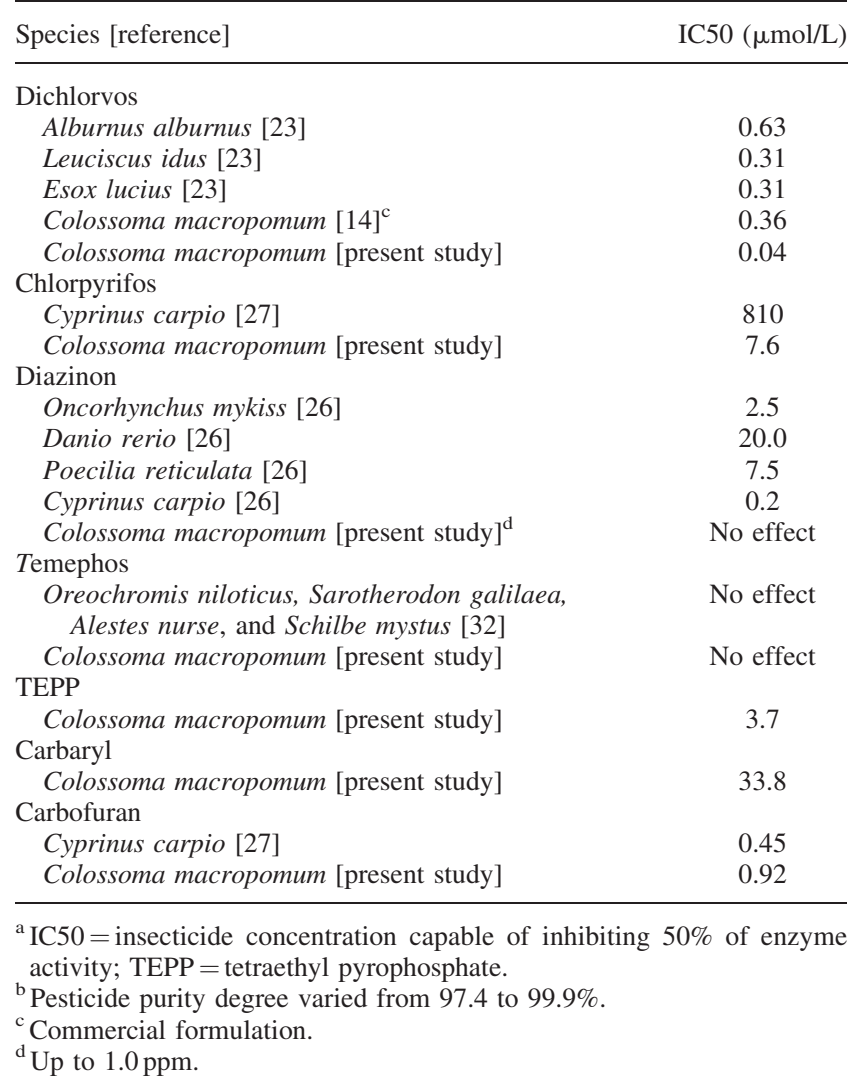

toxicity to mammals and other nontarget organisms, and is commonly used in potable water treatment against mosquito larva vectors of diseases in public health campaigns [31]. Tetraethyl pyrophosphate displayed an IC50 value of $3.7 \mu \mathrm{mol} / \mathrm{L}$. This is an organophosphorus known to be highly toxic to mammals; it is the biotransformation product of another pesticide, which is classified as extremely hazardous by the World Health Organization [32]. Table 3 displays its in vivo LC50 for other fish species provided by the U.S. Environmental Protection Agency Ecotoxicology Database (http://cfpub.epa.gov/ECOTOX/), which reflects the high toxicity of this compound $\left(6.8 \mathrm{~h}\right.$ at $\left.25^{\circ} \mathrm{C}\right)$ [33]. Tetraethyl pyrophosphate is currently classified as an obsolete pesticide [32], but in fact is responsible for part of the toxic action in some organophosphate products, such as diazinon, chlorpyrifos, parathion, and demeton, where it appears as an impurity or breakdown product due to the manufacturing process or unsuitable storage conditions [33]. The two analyzed carbamate insecticides, carbaryl and carbofuran, presented IC50 values of $33.8 \mu \mathrm{mol} / \mathrm{L}$ and

Table 3. TEPP LC50 in several fish species ${ }^{\mathrm{a}, \mathrm{b}}$

\begin{tabular}{lcc}
\hline Species & TEPP $(\%)$ & LC50 (mg/L) \\
\hline Carassius auratus & 40.0 & 21.00 \\
Gambusia affinis & 40.0 & 2.84 \\
Ictalurus punctatus & 40.0 & 1.60 \\
Lepomis macrochirus & 40.0 & 0.79 \\
Pimephales promelas & 40.0 & 1.00 \\
Poecilia reticulata & 40.0 & 1.80 \\
Oncorhynchus tshawytscha & 40.0 & 0.31 \\
\hline a TEPP $=$ tetraethyl pyrophosphate; LC50 & $=$ concentration resulted in death \\
for half of the animals. & & \\
${ }^{\mathrm{b}}$ Source: U.S. Environmental Protection Agency ECOTOX Database.
\end{tabular}

$0.99 \mu \mathrm{mol} / \mathrm{L}$, respectively. The latter IC50 value is similar to that reported by Dembélé et al. for in vitro, Cyprinus carpio [26], namely, $0.45 \mu \mathrm{mol} / \mathrm{L}$ (0.1 ppm).

The monitoring of pesticides such as organophosphates and carbamates can be evaluated by using organisms in aquatic environments (in vivo assays). In these cases, tanks, animal manipulation, feeding demands, and specially trained personnel are required. Otherwise, animals can be collected from their environment and these toxic components analyzed in their tissues. The use of enzymes, namely, cholinesterases, allows in vitro procedures that are less costly, less time-consuming, less laborious, and more sensitive. The analysis of reactions can take place without interfering compounds present in tissues or animal sensors that could interact with anticholinesterasic agents, thereby causing false positives or negatives. Moreover, biosensors based on these enzymes can be built and used in environmental monitoring. The findings described here confirm previous findings [14] related to the sensitivity of AChE from the brain of the juvenile Amazonian tambaqui towards dichlorvos, and its possible use as the biocomponent of in vitro sensor for this pesticide, and also for chlorpyrifos, carbaryl, and carbofuran.

Acknowledgement - The authors thank Financiadora de Estudos e Projetos (FINEP), Petróleo do Brasil S/A (PETROBRAS), Ministério da Aqüicultura e Pesca (MAP), Conselho Nacional de Pesquisa e Desenvolvimento Científico (CNPq), and Fundação de Apoio à Ciência e Tecnologia do Estado de Pernambuco (FACEPE) for financial support. Mar Doce Piscicultura e Projetos also deserve our thanks for providing tambaqui juveniles specimens.

\section{REFERENCES}

1. Hart KA, Pimentel D. 2002. Environmental and economic costs of pesticide use. In Pimentel D, ed, Encyclopedia of Pest Management. Marcel Dekker, New York, NY, USA pp 237-239.

2. Marco M-P, Barceló D. 1996. Environmental applications of analytical biosensors. Meas Sci Technol 7:1547-1562.

3. Amine A, Mohammad H, Bourais I, Palleschi G. 2006. Enzyme inhibition-based biosensors for food safety and environmental monitoring. Biosens Bioelectron 21:1405-1423.

4. Beauvais SL, Cole KJ, Atchison GJ, Coffey M. 2002. Factors affecting brain cholinesterase activity in Bluegill (Lepomis macrochirus). Water Air Soil Pollut 135:249-264.

5. Rodríguez-Fuentes G, Gold-Bouchot G. 2004. Characterization of cholinesterase activity from different tissues of Nile tilapia (Oreochromis niloticus). Mar Environ Res 58:505-509.

6. Rodríguez-Fuentes G, Armstrong J, Schlenk D. 2008. Characterization of muscle cholinesterases from two demersal flatfish collected near a municipal wastewater outfall in Southern California. Ecotoxicol Environ Saf 69:466-471.

7. Fairbrother A, Bennett JK. 1988. The usefulness of cholinesterase measurements. J Wild Dis 24:587-590.

8. Quinn DM. 1987. Acetylcholinesterase: Enzyme structure, reaction dynamics, and virtual transition states. Chem Rev 87:955-979.

9. Bocquené G, Galgani F, Truquet P. 1990. Characterization and assay conditions for use of AChE activity from several marine species in pollution monitoring. Mar Environ Res 30:75-89.

10. Rodríguez-Fuentes G, Gold-Bouchot G. 2000. Environmental monitoring using acetylcholinesterase inhibition in vitro. A case study in two Mexican lagoons. Mar Environ Res 50:357-360.

11. Sturm A, Wogram J, Hansen P, Liess M. 1999. Potential use of cholinesterase in monitoring low levels of organophosphates in small streams: Natural variability in three-spined stickleback (Gasterosteus aculeatus). Environ Toxicol Chem 18:194-200.

12. Valdés-Ramírez G, Fournier D, Ramírez-Silva MT, Marty J-L. 2008. Sensitive amperometric biosensor for dichlorovos quantification: Application to detection of residues on apple skin. Talanta 74:741-746.

13. Tõugu V. 2001. Acetylcholinesterase: Mechanism of catalysis and inhibition. Curr Med Chem-Cent Nerv Syst Agents 1:155-170.

14. Assis CRD, Amaral IPG, Castro PF, Carvalho LB Jr, Bezerra RS. 2007. Effect of dichlorvos on the acetylcholinesterase from tambaqui (Colossoma macropomum) brain. Environ Toxicol Chem 26:1451-1453. 
15. Sedmak JJ, Grossberg SE. 1977. A rapid, sensitive and versatile assay for protein using Coomassie brilliant blue G250. Anal Biochem 79:544-552.

16. Coppage DL. 1971. Characterization of fish brain acetylcholinesterase with an automated $\mathrm{pH}$ stat for inhibition studies. Bull Environ Contam Toxicol 6:304-310.

17. Cunha Bastos VLF, Cunha Bastos Neto J, Mendonça RL, Faria MVC. 1988. Main kinetic characteristics of acetylcholinesterase from brain of Hypostomus punctatus, a Brazilian bentonic fish (cascudo). Comp Biochem Physiol C Comp Pharmacol 91:327-331.

18. Hazel J. 1969. The effect of thermal acclimation upon brain acetylcholinesterase activity of Carassius auratus and Fundulus heteroclitus. Life Sci 8:775-784.

19. Zinkl JG, Shea PJ, Nakamoto RJ, Callman J. 1987. Technical and biological considerations for the analysis of brain cholinesterase from rainbow trout. Trans Am Fish Soc 116:570-573.

20. Varó I, Navarro JC, Nunes B, Guilhermino L. 2007. Effects of dichlorvos aquaculture treatments on selected biomarkers of gilthead sea bream (Sparus aurata L.) fingerlings. Aquaculture 266:87-96.

21. Food and Agriculture Organization. 2007. C Pesticides in food report 2007.FAO Plant Production and Protection Paper 191. Rome, Italy.

22. Chuiko GM. 2000. Comparative study of acetylcholinesterase and butyrylcholinesterase in brain and serum of several freshwater fish: Specific activities and in vitro inhibition by DDVP, an organophosphorus pesticide. Comp Biochem Physiol C Comp Pharmacol 127:233-242.

23. World Health Organization/International Programme on Chemical Safety/INCHEM. 1989. Dichlorvos. Environmental Health Criteria 79. Geneva, Switzerland.

24. Cunha Bastos VLF, Silva Filho MV, Rossini A, Cunha Bastos J. 1999. The activation of parathion by brain and liver of a Brazilian suckermouth benthic fish shows comparable in vitro kinetics. Pestic Biochem Physiol 64:149-156.
25. Keizer J, D’Agostino G, Nagel R, Volpe T, Gnemid P, Vittozzi L. 1995. Enzymological differences of $\mathrm{AChE}$ and diazinon hepatic metabolism: Correlation of in vitro data with the selective toxicity of diazinon to fish species. Sci Total Environ 171:213-220.

26. Dembélé K, Haubruge E, Gaspar C. 2000. Concentration effects of selected insecticides on brain acetylcholinesterase in the common carp (Cyprinus carpio L.). Ecotoxicol Environ Saf 45:49-54.

27. Keizer J, D’Agostino G, Nagel R, Gramenzi F, Vittozzi L. 1993. Comparative diazinon toxicity in guppy and zebrafish: Different role of oxidative metabolism. Environ Toxicol Chem 12:12431250.

28. Livingstone DR. 1998. The fate of organic xenobiotics in aquatic ecosystems: Quantitative and qualitative differences in biotransformation by invertebrates and fish. Comp Biochem Physiol Part A Mol Integr Physiol 120:43-49.

29. Boone JS, Chambers JE. 1997. Biochemical factors contributing to toxicity differences among chlorpyrifos, parathion, and methyl parathion in mosquitofish (Gambusia affinis). Aquat Toxicol (Amst) 39:333-343

30. Magnum C, Towle D. 1977. Physiological adaptation to unstable environments. Am Sci 65:67-75.

31. Antwi LAK. 1987. Fish head acetylcholinesterase activity after aerial application of temephos in two rivers in Burkina Faso, West Africa. Bull Environ Contam Toxicol 38:461-466.

32. World Health Organization/United Nations Environment Programme/ International Labour Organization/International Programme on Chemical Safety. 2006. The WHO recommended classification of pesticides by hazard. World Health Organization, Geneva, Switzerland

33. National Registration Authority. 2002. The NRA review of diazinon. NRA Draft Chemistry v. 2. National Registration Authority, Canberra. Australia. 